\title{
Repeated Binge-Like Ethanol Administration During Adolescence cause Decreased C-Fos Immunoreactivity in Amygdala and Arcuate Nucleus in Adult Sprague-Dawley Rats
}

\author{
La Administración Repetida de Etanol, Tipo Atracón, Durante la Adolescencia Provoca Descenso \\ en la Expresión de C-Fos en la Amígdala y Núcleo Arqueado de Ratas Sprague-Dawley Adultas
}

\author{
Jose Manuel Lerma-Cabrera,***; Francisca Carvajal,***; Manuel Alcaraz-Iborra*; \\ Maria del Carmen Sanchez-Amate*; Leticia de la Fuente \& Inmaculada Cubero*
}

LERMA-CABRERA, J. M.; CARVAJAL, F.; ALCARAZ-IBORRA, M.; SANCHEZ-AMATE, M. C.; DE LA FUENTE, L. \& CUBERO, I. Repeated binge-like ethanol administration during adolescence cause decreased c-fos immunoreactivity in amygdala and arcuate nucleus in adult Sprague-Dawley rats. Int. J. Morphol., 32(2):575-582, 2014.

SUMMARY: Binge alcohol drinking during adolescence has been associated with neurotoxicity and increased risk for the development of alcohol use disorders. There is evidence that acute and chronic ethanol administration alters c-fos expression, an indirect index of cellular activity, in different brain regions in adult rats. We evaluate here if a binge-like pattern of ethanol exposure during adolescence has a relevant impact on basal and/or ethanol-stimulated regional c-fos activity during adulthood. For that aim, SpragueDawley rats PND 25 were saline pre-treated, (SP group) or binge-ethanol pre-treated (BEP group) for two-consecutive days, at 48-h intervals, over a 14-day period (PND 25 to PND 38). At adult stage (PND 63) and following 25 ethanol-free days, we evaluated c-fos immunoreactivity in response to saline or acute ethanol $(1.5$ or $3.0 \mathrm{~g} / \mathrm{kg})$ in the hypothalamus and amygdala. We found that acute ethanol administration dose-dependently increased c-fos activity in the the Paraventricular nucleus of the hypothalamus (PVN). Interestingly, binge-ethanol exposure during adolescence significantly reduced basal c-fos activity during adulthood in the Central nucleus of the amygdala (CeA) and the Arcuate nucleus of hypothalamus (Arc). We conclude that binge-like ethanol administration during adolescence causes long-term disturbances in basal neural activity in brain areas critically involved with ethanol consumption.

KEY WORDS: C-Fos; Immunoreactivity; Rats; Binge-like ethanol administration; Adolescent; Arcuate nucleus of hypothalamus (Arc); Central nucleus of the amygdala (CeA); Paraventricular nucleus of the hypothalamus (PVN).

\section{INTRODUCTION}

Binge alcohol drinking is a widespread behavior among adolescents that constitutes a worrying phenomenon predicting an increased prevalence of alcoholism in future societies. The National Institute on Alcohol Abuse and Alcoholism (2004) defines binge-like drinking as the consumption of 4-5 drinks within about $2 \mathrm{~h}$, reaching blood ethanol concentration of $0.08 \mathrm{~g} / \mathrm{dL}$. In USA, about $57 \%$ of 12 to 21-year olds exhibit this pattern of heavy drinking (Substance Abuse and Mental Health Services Administration, 2009). According to the data of National Service for Drug and Alcohol Prevention and Rehabilitation (SENDA), $59.37 \%$ of 13 to 17 -year old Chilean people exhibit this pattern (Observatorio Chileno de Drogas. Servicio Nacional para la Prevención y Rehabilitación del Consumo de Drogas y Alcohol (SENDA), 2013).
Adolescence is an important period of brain development characterized by high vulnerability to ethanol exposure (Pascual et al., 2009). Animal research has provided consistent evidence that binge-like ethanol exposure during this period causes long-lasting neuroadaptive changes in neural pathways that are critically involved in the neurobehavioral responses to ethanol (Lerma-Cabrera et al., 2013; Przybycien-Szymanska et al., 2011; Logrip et al., 2013), increases the risk of ethanol consumption and preference during adulthood, and promotes inhibition of molecular and cellular neuroadaptations (Pascual et al.), in adult rats. These adaptations led to the hypothesis that long-term plasticity is one important underlying mechanism involved in addiction (Nestler, 2004).

\footnotetext{
* Departamento de Neurociencia y Ciencias de la Salud, Universidad de Almería, Almería, Spain.

** Carrera de Psicología, Facultad Ciencias Jurídicas y Sociales, Universidad Autónoma de Chile, Santiago, Chile.
} 
The expression of the c-fos activity has been used as an anatomical marker of activated brain areas. In animals, there is evidence that acute ethanol administration triggers c-fos expression in several brain regions (Chang et al., 1995; Ogilvie et al., 1998), a phenomenon which has been associated to activation of intracellular pathways (Curran \& Morgan, 1995). Alternatively, in adult rats chronic ethanol exposure reduces in several rat brain areas including the bed nucleus of the stria terminalis (BNST), paraventricular hypothalamic nucleus (PVN), the central nucleus of amygdala (CeA), Edinger-Westphal nucleus (EW), locus coeruleus nucleus (LC) and parabrachial nucleus (PB), cfos expression triggered by i.p. ethanol administration (Chang et al.). Also, short-time abstinence (hours or days) induced in rats an increase in c-fos immunoreactivity in all major part of the brain (for a review see, Vilpoux et al., 2009). In brief, molecular data in animal ethanol research indicates that ethanol exposure, both acute and chronic, significantly alters brain regional cellular activity as measured by c-fos immunoreactivity. However, whether ethanol exposure during adolescence alters basal and/or ethanol-elicited regional c-fos immunoreactivity in the adult brain remains unknown.

The present study addresses whether a binge-like pattern of ethanol exposure known to elicit during adolescence (postnatal days (PND) 25-38) promotes basal and/or ethanol elicited c-fos immunoreactivity later during adulthood (PND 63) in regions of the hypothalamus and $\mathrm{CeA}$, which are key brain regions known to be involved in the neurobiological responses to ethanol and ethanol consumption. Furthermore, the previous study found that binge-like ethanol exposure during adolescence significantly reduced basal $\alpha$-MSH IR in the central CeA, PVN and the arcuate nucleus of the hypothalamus (Arc) during adulthood (Lerma-Cabrera et al., 2013).

\section{MATERIAL AND METHOD}

Animals. Sixty Sprague-Dawley rat pups on postnatal day (PND 25) (Charles River Laboratories, Spain) were used as subjects in these experiments. Pups remained housed in groups of four rats per cage and maintained in an environmentally controlled room $\left(22^{\circ} \mathrm{C}\right.$ temperature on a $12: 12 \mathrm{~h}$ light-dark cycle). Standard rodent chow and water were provided ad libitum throughout the experiments and all the manipulations were conducted during the dark phase. Behavioral procedures and pharmacological techniques were in compliance with the animal care guidelines established by the Spanish Royal Decrees 1025/2005 for reducing animal pain and discomfort and the protocols were approved by the University of Almería Bioethical Animal Care and Use Committee.

Ethanol exposure. Morning doses of either 25\% (w/v) ethanol $(3.0 \mathrm{~g} / \mathrm{kg})$ in isotonic saline, or saline, were administered intraperitoneally (i.p.) to 25-day old pups on two consecutive days with gaps of 2 days without injections, during 2 weeks. Specifically, pups were injected at PND 25, $26,29,30,33,34,37$ and 38 . In this way each young rat received eight alcohol doses simulating the binge, an intermittent drinking pattern characteristic of young students and adolescents (Pascual et al.; Lerma-Cabrera et al., 2013) (Fig. 1).

\section{Perfusions, Brain Preparation, and Immunohistochemistry} (IHC). Twenty five days after the final injection (adult stage, PND63), animals were injected with ethanol i.p. (25\% v/w, mixed in isotonic saline) in one of three possible doses: saline; $1.5 \mathrm{~g} / \mathrm{kg}$ or $3.0 \mathrm{~g} / \mathrm{kg}$ and the brain processed to quantify ethanol-induced immunoreactivity expression in ethanol and saline-pretreated rats in adolescence.

The animals were euthanized two hours post-ethanol administration with an overdose of sodium pentothal (80 $\mathrm{mg} / \mathrm{kg}$ in $1 \mathrm{mg} / \mathrm{kg}$ volume) and transcardially perfused with phosphate buffered saline (PBS) followed by $0.1 \mathrm{M}$ phosphate buffered paraformaldehyde $4 \%$ (PH 7.4). The 2 hours post-injection perfusion time was chosen because we have previously found treatment induced differences in protein at this time interval (Thiele et al., 1997, 1998). The brains were removed and post-fixed in paraformaldehyde for $48 \mathrm{~h}$ at $4^{\circ} \mathrm{C}$, at which point they were transferred to PBS. Cerebral sections were cut in coronal section $50 \mu \mathrm{m}$ thick with a motorized vibrotome and stored in PBS until the IHC assay. Sections were evenly divided into three sets (everyother section) for processing with c-fos antibodies. A total of 4 different brain regions were collected based on Paxinos \& Watson (1998) stereotaxic atlas coordinates: the arcuate hypothalamic nucleus (Arc), bregma -2.12 to $-2.8 \mathrm{~mm}$; the

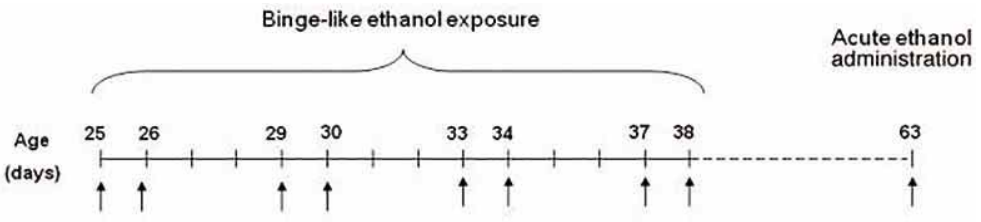

Fig. 1. Schematic temporal representation of ethanol injections during bingelike ethanol pre-treatment during adolescence beginning on PND25. Twentyfive days after the last injection was administered, adult rats were tested on PND63 with one of two acute doses of ethanol $(1.5 \mathrm{~g} / \mathrm{kg}$ or $3 \mathrm{~g} / \mathrm{kg})$ or saline to evaluate basal and ethanol-stimulated regional c-fos expression. 
central nucleus of amygdala (CeA), bregma -3.14 to -2.30 $\mathrm{mm}$; the paraventricular nucleus of hypothalamus (PVN), bregma -1.8 to $-2.12 \mathrm{~mm}$; and lateral hypothalamic area $(\mathrm{LH})$ bregma -1.8 to $-2.56 \mathrm{~mm}$.

Immunohistochemistry for c-Fos expression. Brain slices were rinsed ( $3 \mathrm{X}, \mathrm{PBS}$ ), incubated for $30 \mathrm{~min}$ in $0.3 \% \mathrm{H} 2 \mathrm{O} 2$ in absolute methanol to quench endogenous peroxidase rinsed (3X, PBS) and incubated for $1 \mathrm{~h}$ in $3 \%$ goat serum in PBS. Slices were then transferred, without rinsing, to the primary antibody solution; which consisted in 1:10000 cfos polyclonal rabbit IgG (Santa Cruz Biotechnology, Santa Cruz, CA) that recognizes residues 3-16 of the c-fos protein. After $36 \mathrm{~h}$ incubation at $4^{\circ} \mathrm{C}$, slices were rinsed (10X, PBS) and processed with $\mathrm{ABC}$ method (Vector Laboratories, Burlingame, CA). Briefly, the slices were transferred to a solution containing biotinylated anti-rabbit IgG for $1 \mathrm{~h}$, rinsed (10X, PBS), transferred to avidin-biotin peroxidase for $1 \mathrm{~h}$ (5X,PBS, $30 \mathrm{~min}$, then 5X, PB, $30 \mathrm{~min}$ ), and developed with nickel-intensified diaminobenzidine substrate $(6 \mathrm{~min})$. Following proper development, slices were rinsed (PBS, 10 min) mounted on slides, and coverslipped with Permount.

Quantification of regional c-fos immunoreactivity (IR). Digital images of c-fos immunohistochemistry were obtained on an Olympus BX50 microscope equipped with a Pixel Link digital camera run with Visiopharm software. For analysis, great care was taken to match sections through the same region of brain and at the same level using anatomic landmarks with the aid of a rat stereotaxic atlas (Paxinos \& Watson). Densitometric procedures were used to assess protein levels. Flat-field corrected digital pictures (8-bit grayscale) were taken using the Pixel Link digital camera and density of staining was analyzed using Image $\mathbf{J}$ software (Image J, National Institute of Health, Bethesda, MD) by calculating the percent of the total area examined that showed signal (cell bodies and processes) relative to a subthreshold background. The size of the areas that were analyzed was the same between animals and groups. The subthreshold level for the images was set in such a way that any area without an experimenter defined level of staining was given a value of zero. Anatomically matched pictures of the left and right sides of the brain were used to produce an average density for each brain region from each slice. In all cases, quantification of immunohistochemistry data was conducted by an experimenter blinder to the experimental conditions.

Data Analyses. All data collected in this study are presented as mean \pm SEM and differences between groups were analyzed using analyses of variance (ANOVA) procedures. Because we expected that ethanol induced alterations of cfos would be site specific, separate ANOVAs were performed for each brain region. Independent two-way, 2 x 3 (pretreatment $\mathrm{x}$ dose) ANOVAs were performed on IHC data collected from each brain region. When significant differences were found, post hoc analyses were conducted using the Newman-Keuls (NK) test. In all cases, $\mathrm{p}<0.05$ (two-tailed) was used as the level of statistical significance.

\section{RESULTS}

C-fos expression in Regions of the Hypothalamus and CeA in saline (SP) and binge-ethanol (BEP) pre-treated groups.

Arcuate Nucleus of hypothalamus. Figure 2A shows data representing the average densities of c-fos immunoreactivity in the Arc of BEP and SP rats given i.p. injection of saline $(\mathrm{n}=7$ and 6 , respectively), a $1.5 \mathrm{~g} / \mathrm{kg}$ dose of ethanol ( $\mathrm{n}=10$

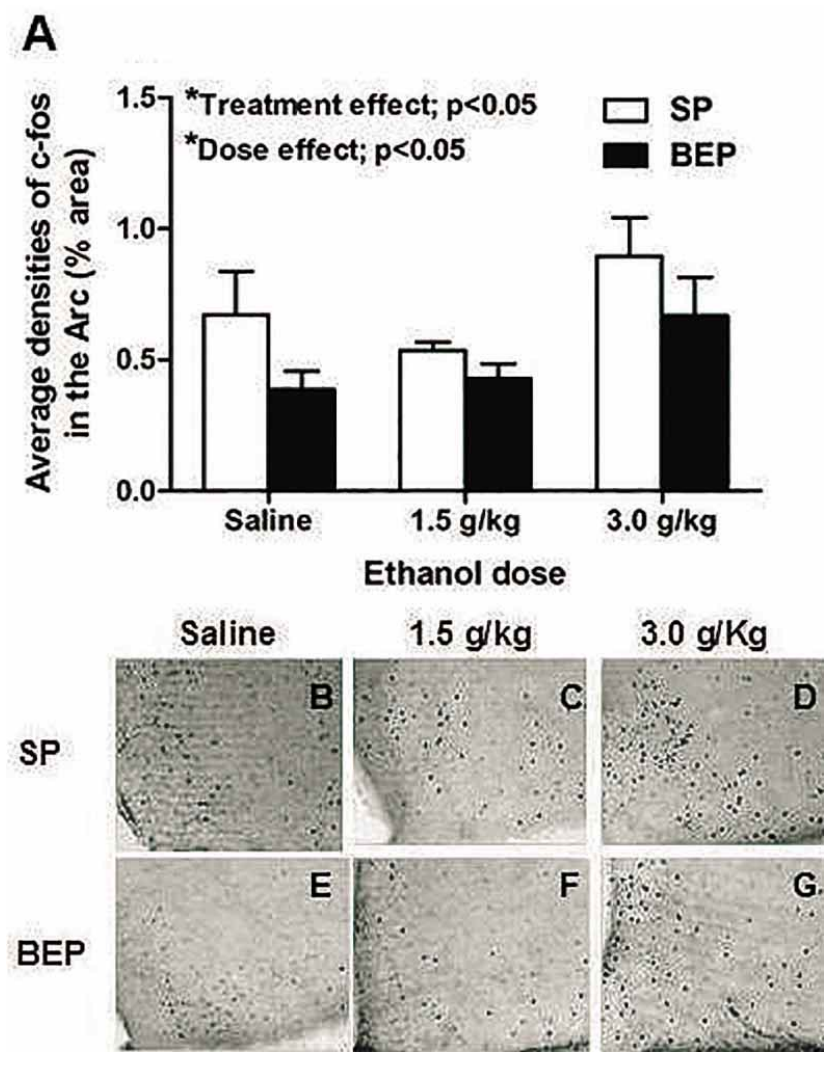

Fig. 2. Quantification of c-fos immunoreactivity ( $\%$ area) in the arcuate nucleus of hypothalamus (Arc; A). Adult rats naïve or preexposed to ethanol in adolescence were given intraperitoneal injection of isotonic saline or a $1.5 \mathrm{~g} / \mathrm{kg}$ or $3.0 \mathrm{~g} / \mathrm{kg}$ dose of ethanol, and brains were collected 2 hours after injections. Representative photomicrographs of $50 \mathrm{~mm}$ coronal sections showing c-fos immunoreactivity (IR) in SP (B, C, D) and $\mathrm{BEP}(\mathrm{E}, \mathrm{F}, \mathrm{G})$ animals receiving saline during the test day are depicted in the figure. Values are represented as mean $\pm \mathrm{SEM}$. 
and 8 , respectively) or a $3.0 \mathrm{~g} / \mathrm{kg}$ dose of ethanol ( $\mathrm{n}=$ 8 and 7, respectively). A two-way ANOVA performed on these data revealed a significant main effect of pretreatment $[\mathrm{F}(1,40)=5.13, \mathrm{p}<0.05]$ and dose $[\mathrm{F}(2$, $40)=4.33, \mathrm{p}<0.05]$. Additional NK tests showed that the high dose of ethanol significantly increased c-fos expression in the Arc compared to c-fos expression induced by saline administration and the low dose of ethanol; however, no differences were observed between ethanol- and saline- pretreated rats in adolescence. The pre-treatment $x$ dose interaction was not statistically significant $[F(2,40)=0.34, p>0.05]$.

Paraventricular nucleus of hypothalamus. Figure $3 \mathrm{~A}$ shows data representing the average densities of c-fos immunoreactivity in the PVN of BEP and SP rats given i.p. injection of saline $(n=5$ and 8 , respectively), a $1.5 \mathrm{~g} / \mathrm{kg}$ dose of ethanol ( $\mathrm{n}=8$ and 10 , respectively) or a $3.0 \mathrm{~g} / \mathrm{kg}$ dose of ethanol ( $\mathrm{n}=8$ and 10 , respectively). A two-way ANOVA performed on these data showed a statistically significant main effect of dose $[F(2,43)=16.58, p<0.001]$. Neither the pretreatment $[F(1,43)=1.458, p>0.05]$ nor the interaction $[F(2,43)=0.454, p>0.05]$ effects were statistically significant. Taken together, these results show that both doses of ethanol produced marked increases in c-fos expression in the PVN, both in BEP and SP rats.

Lateral hypothalamic area. Figure 4 shows data representing the average densities of $\mathrm{c}$-fos immunoreactivity in the LH of BEP and SP rats given i.p. injection of saline ( $\mathrm{n}=6$ and 8 , respectively), a 1.5 $\mathrm{g} / \mathrm{kg}$ dose of ethanol ( $\mathrm{n}=8$ and 10 , respectively) or a $3.0 \mathrm{~g} / \mathrm{kg}$ dose of ethanol ( $\mathrm{n}=7$ and 10 , respectively). A two-way ANOVA performed on these data revealed that neither the pre-treatment effect $[\mathrm{F}(1,43)=0.355$, $p>0.05]$, the dose effect $[F(2,43)=1.644, p>0.05]$ nor the pre-treatment $\mathrm{x}$ dose interaction $[\mathrm{F}(2,43)=$ $0.840, \mathrm{p}>0.05]$ attained statistical significance.

Central nucleus of amygdala. Figure 5A shows data representing the average densities of $\mathrm{c}$-fos immunoreactivity in the CeA of BEP and SP rats given

Fig. 4. Quantification of c-fos immunoreactivity (\% area) in the lateral nucleus of the hypothalamus (LH). Adult rats naïve or pre-exposed to ethanol in adolescence were given intraperitoneal injection of isotonic saline or a $1.5 \mathrm{~g} / \mathrm{kg}$ or $3.0 \mathrm{~g} / \mathrm{kg}$ dose of ethanol, and brains were collected 2 hours after injections. Values are represented as mean \pm SEM.
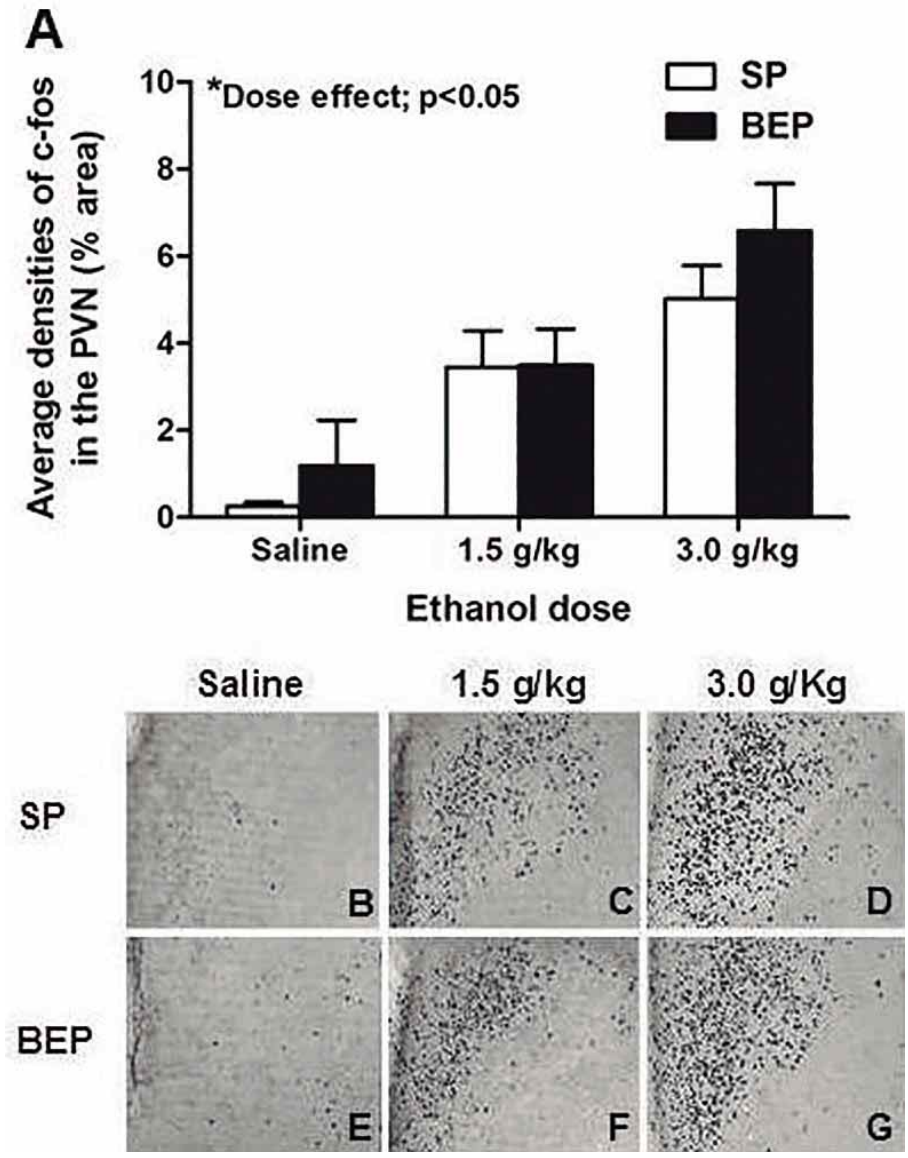

Fig. 3. Quantification of c-fos immunoreactivity (\% area) in the paraventricular nucleus of the hypothalamus (PVN; A). Adult rats naïve or pre-exposed to ethanol in adolescence were given intraperitoneal injection of isotonic saline or a $1.5 \mathrm{~g} / \mathrm{kg}$ or $3.0 \mathrm{~g} / \mathrm{kg}$ dose of ethanol, and brains were collected 2 hours after injections. Representative photomicrographs of $50 \mathrm{~mm}$ coronal sections showing c-fos immunoreactivity $(\mathrm{IR})$ in $\mathrm{SP}(\mathrm{B}, \mathrm{C}, \mathrm{D})$ and $\mathrm{BEP}(\mathrm{E}, \mathrm{F}, \mathrm{G})$ animals receiving saline during the test day are depicted in the figure. Values are represented as mean \pm SEM.

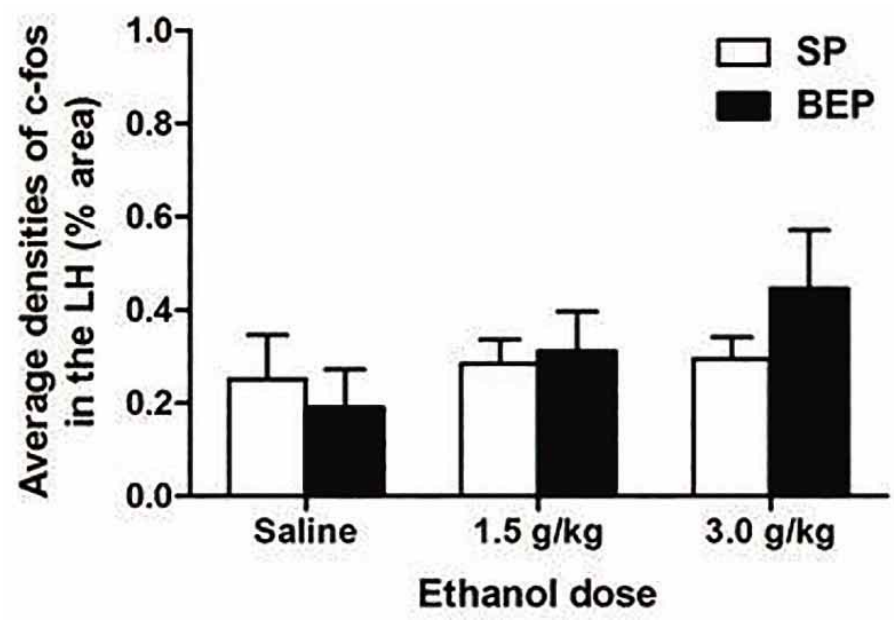


i.p. injection of saline ( $\mathrm{n}=6$ and 8 , respectively), a $1.5 \mathrm{~g} / \mathrm{kg}$ dose of ethanol ( $\mathrm{n}=8$ and 10 , respectively) or a $3.0 \mathrm{~g} / \mathrm{kg}$ dose of ethanol $(\mathrm{n}=8$ and 9, respectively). A two-way ANOVA performed on these data revealed a significant main effect of pre-treatment $[\mathrm{F}(1,43)=5.661, \mathrm{p}<$ $0.05]$ and dose $[F(2,43)=11.05, p<0.01]$, but the pre-treatment $x$ dose interaction was not statistically significant $[\mathrm{F}(2,43)=1.102, \mathrm{p}>0.05]$. Additional NK tests showed that the high dose of ethanol significantly increased c-fos expression in the CeA compared to c-fos expression induced by saline administration and the low dose of ethanol, both in BEP and SP rats.

A

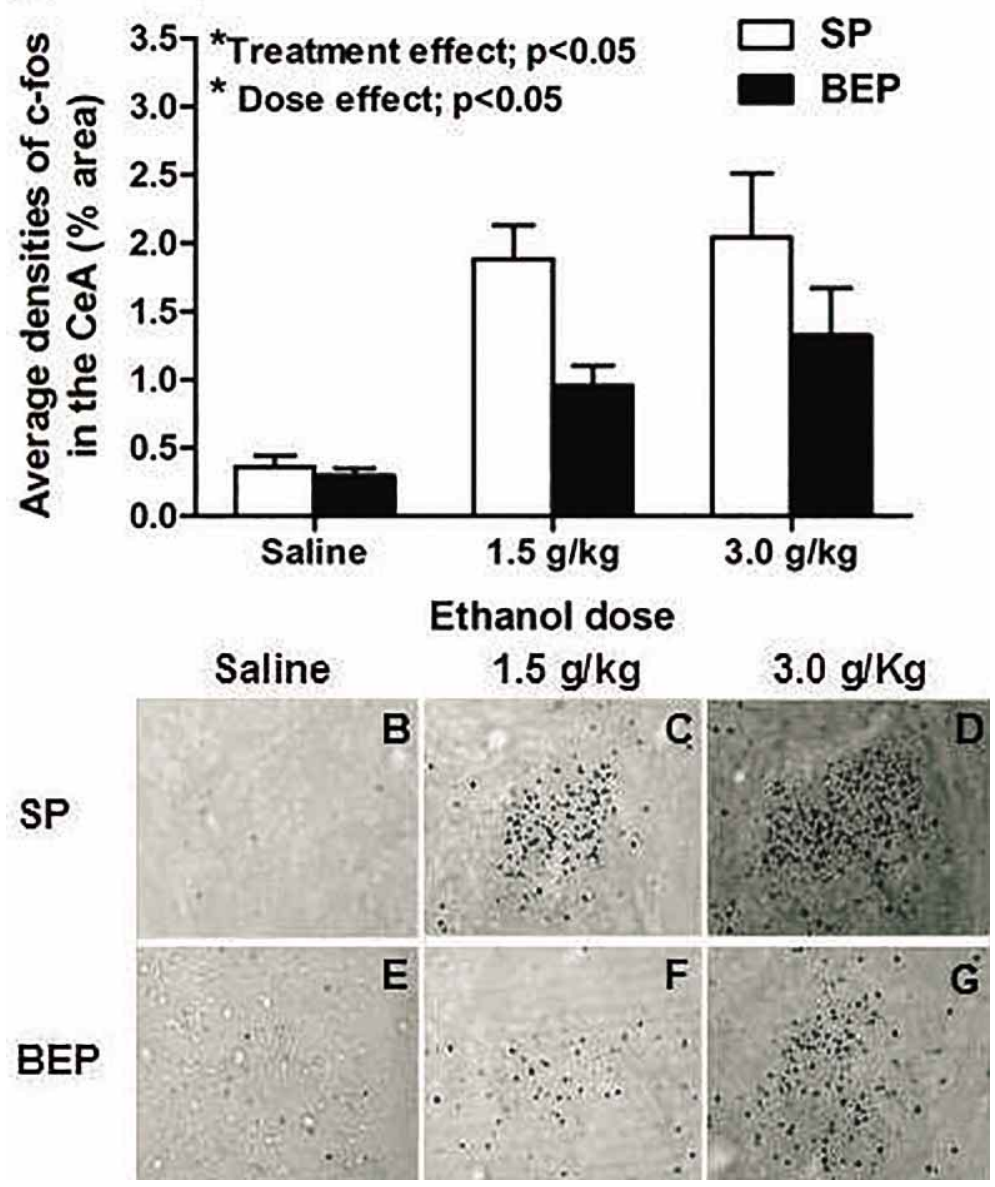

Fig. 5. Quantification of c-fos immunoreactivity (\% area) in the central nucleus of amygdala (CeA; A). Adult rats naïve or pre-exposed to ethanol in adolescence were given intraperitoneal injection of isotonic saline or a $1.5 \mathrm{~g} / \mathrm{kg}$ or $3.0 \mathrm{~g} / \mathrm{kg}$ dose of ethanol, and brains were collected 2 hours after injections. Representative photomicrographs of $50 \mathrm{~mm}$ coronal sections showing c-Fos immunoreactivity (IR) in $\mathrm{SP}(\mathrm{B}, \mathrm{C}, \mathrm{D})$ and $\mathrm{BEP}(\mathrm{E}, \mathrm{F}, \mathrm{G})$ animals receiving saline during the test day are depicted in the figure. Values are represented as mean \pm SEM.

\section{DISCUSSION}

The purpose of the work presented here was to address whether binge-like ethanol exposure during adolescence alters basal and/or ethanol induced c-fos IR later during adulthood in $\mathrm{CeA}$ and hypothalamic brain region. The main results we report here are: 1) binge-like ethanol pre-treatment during adolescence reduced basal c-fos IR in the Arc and CeA during adulthood; 2) acute ethanol increased c-fos IR in the Arc, PVN and CeA when tested during adulthood in both the SP and BEP groups.

The first important observation in the study shows that Sprague-Dawley rats exposed to repeat binge-like ethanol administration during adolescence exhibited significant reductions of basal c-fos IR in the Arc and the $\mathrm{CeA}$ during adulthood, relative to rats exposed to saline. It has been proposed that the sensitization of c-fos expression in response to chronic administration of ethanol is indicative of the process of cellular adaptation or neuronal plasticity at the level of gene regulation, as a result of chronic usage of ethanol (Chang et al.). Because neuroadaptation may constitute part of the long-term, long-lasting neural changes that take place in addiction (Nestler), reduced c-fos induction during adulthood in response to continued binge-like ethanol administration over the adolescence might be an indirect index of unknown long-lasting cellular adaptive mechanisms that contributes to altered ethanol consumption. Regarding basal changes in c-fos IR the $\mathrm{CeA}$, the present finding is consistent with previous studies demonstrating that continued ethanol injections for 17 or 24 days provoked desensitization of c-fos activity in the CeA when compared to acute ethanol exposure (Chang et al.; Ryabinin et al., 1997). Given the well-known roles of the hypothalamus and the amygdala in ethanol intake (Allen et al., 2011; Gilpin \& Roberto, 2012), and the fact that binge-like ethanol exposure during adolescence increases the probability of ethanol consumption during adulthood (Pascual et al.), it is tempting to propose that long-lasting reduction of $\mathrm{c}$ - fos IR in the Arc and CeA by binge-like ethanol pretreatment during adolescence might contribute to the increased vulnerability to ethanol consumption during adulthood.

Bedside, the basal altered c-fos IR in the Arc of BEP rats, raises an interesting possibility of altered activity in the Melanocortin system (MC). Central MC peptides are produced by neurons in the Arc and include 
LERMA-CABRERA, J. M.; CARVAJAL, F.; ALCARAZ-IBORRA, M.; SANCHEZ-AMATE, M. C.; DE LA FUENTE, L. \& CUBERO, I. Repeated binge-like ethanol administration during adolescence cause decreased c-fos immunoreactivity in amygdala and arcuate nucleus in adult Sprague-Dawley rats. Int. J. Morphol., 32(2):575-582, 2014.

adrenocorticotropic hormone, a-melanocyte stimulating hormone (a-MSH) (Cone, 2005). Agouti related-protein (AgRP), a neuropeptide produced in the hypothalamus and co-secreted with neuropeptide Y (NPY) in the same synaptic complexes as a-MSH, functions as a natural MC receptor (MCR) antagonist (Cone, 2005). MC neuropeptides, in the brain, act through at $\mathrm{MC} 3$ receptor (MC3R) and MC4R (Cone). Central administration of potent non-selective MCR agonist melanotan-II (MTII) and a selective MC4R agonist significantly reduced voluntary ethanol in adult mice and rats (Navarro et al., 2005, 2011; Lerma-Cabrera et al., 2012), but not MTII administration in Mc4r-/- mice (Navarro et al., 2011). Central AgRP and HS014, MC4R antagonist administration increases voluntary ethanol consumption in mice and rats (Navarro et al., 2005; Lerma-Cabrera et al., 2012). In another way, binge-like ethanol exposure during adolescence significantly reduced basal $\alpha$-MSH IR in the Arc and acute i.p. ethanol administration increased AgRP IR in the Arc (Cubero et al., 2010; Lerma-Cabrera et al., 2013). Taken together, available pharmacological, genetic and immunohistochemistry experimental evidence, and i.c.v administration of MTII increased c-fos IR in the Arc (Thiele et al., 1998), we speculate that present data showing altered c-fos IR in the Arc of adult animals previously exposed to a binge-like ethanol exposure pattern during adolescence might reflect long-term ethanol-promoted basal changes in Melanocortinergic activity in the Arc. Additional immunohistochemical double labelling studies aimed to describe the phenotypic nature of cells showing altered cfos activity, as measured by co-localization of c-fos in MC-neurons, are needed for the further test of this hypothesis.

The second relevant observation in the study is that acute administration of ethanol elicited an increase of cfos IR in the Arc, the PVN and CeA, but not in the LH, which is consistent with previous molecular evidence (Chang et al.; Thiele et al., 1997; Vilpoux et al.). Acute i.p. ethanol increased c-fos IR in the CeA and the PVN in rats (Chang et al.). This is the first study to our knowledge showing the increased c-fos IR in the Arc in response to acute administration of ethanol. Present data showing that acute ethanol administration activates the Arc provides additional evidence to the hypothesis that holds a key role for the MC system in neurobiological responses to ethanol and ethanol consumption (Chang et al.; Thiele et al., 1997).

In our study we did not find evidence of significant c-fos activity in the LH as a result of chronic ethanol administration during adolescence. This result contrasts with previous evidence showing that in adult rats increased c-fos IR in the LH following 14 days of moderate ethanol administration ( $1.5 \mathrm{~g} / \mathrm{kg}$ i.p.) (Ryabinin et al.). In the present study, we used young rats that received eight alcohol doses simulating the binge ( $3.0 \mathrm{~g} / \mathrm{kg}$ i.p. $)$, an intermittent drinking pattern characteristic of young students and adolescents. Given that binge-like ethanol exposure during adolescence increases the probability of ethanol consumption during adulthood (Pascual et al.), it is tempting to propose that $\mathrm{LH}$ is implicated the development of ethanol dependence, but not implicated in the vulnerability to ethanol consumption during adulthood. Nonetheless, the observation that binge-like ethanol pretreatment reduced c-fos IR in some, but not all, regions, suggests that the effects are brain-region specific and limits the possibility that reductions in c-fos IR reflect nonspecific ethanol-induced cellular toxicity.

One possibility for present differences found in ethanol pre-exposed vs. non pre-exposed animals in c-fos IR animals in response to acute ethanol is the existence of group differences in peripheral ethanol metabolism. Arguing against this explanation, a recent study carried out in our labs demonstrated that binge-like ethanol pre-treatment during adolescence does not significantly alters blood ethanol concentration achieved in response to acute ethanol administration in comparison with saline pre-treated group during adulthood (Lerma-Cabrera et al., 2013). Nonetheless, given that several studies have shown that in adolescence the rates of ethanol metabolism reach (Silveri \& Spear, 2000) or slightly exceed (Brasser \& Spear, 2002) those of adult animals, it is premature to completely rule out the existence of mild metabolic disturbance in BEP rats.

In brief, we show here for the first time that bingelike ethanol treatment during adolescence significantly reduces basal c-fos IR in the Arc and the CeA during adulthood. It is possible that reduced c-fos signalling from adolescent binge-like ethanol exposure reveals unknown neural adaptations that may contribute to the increased vulnerability to initiate ethanol consumption in adulthood. The functional connection between reduced $\mathrm{c}$-fos IR in $\mathrm{CeA}$ and the Arc and those behavioural effects observed after binge-like ethanol exposure during adolescence is a topic that warrants further investigation.

\section{ACKOWLEDGEMENTS}

This work was supported by MEC grants (Spain), [SEJ2006-03629, PSI2009-07677], Junta de Andalucia grant [CTS-1350], FEDER [UNAM05-23-006], NIH grant [AA013573, AA015148] and the Department of Defense grants [W81XWH-06-1-0158, W81XWH-09-1-0293]. 
LERMA-CABRERA, J. M.; CARVAJAL, F.; ALCARAZ-IBORRA, M.; SANCHEZ-AMATE, M. C.; DE LA FUENTE, L. \& CUBERO, I. La administración repetida de etanol, tipo atracón, durante la adolescencia provoca descenso en la expresión de c-fos en la amígdala y núcleo arqueado de ratas Sprague-Dawley adultas. Int. J. Morphol., 32(2):575-582, 2014.

RESUMEN: El consumo en atracón durante la adolescencia está asociado con neurotoxicidad y con el riesgo de desarrollar un trastorno en el uso de alcohol. Diversos estudios muestran que la administración aguda y crónica de alcohol en ratas adultas altera la expresión de c-fos, un marcador indirecto de actividad celular, en diferentes áreas cerebrales. Nosotros evaluamos si el patrón de consumo de alcohol en atracón durante la adolescencia tiene un impacto en la actividad basal de c-fos en esas regiones activadas por el alcohol. Utilizamos ratas SpragueDawley en su día post-natal 25 (PND25) tratadas con suero salino (grupo SP) o con etanol tipo atracón (grupo BEP) durante dos días consecutivos, en intervalos de 48 h, durante 14 días (PND25- PND38). En la edad adulta (PND63) y después de 25 días sin etanol, evaluamos la inmunorreactividad para c-fos en respuesta a una administración aguda de suero salino o etanol (1,5 ó 3,0 g/kg) en diferentes regiones cerebrales. La administración de alcohol incrementó de manera dosis-dependiente la actividad de c-fos en el núcleo paraventricular del hipotálamo. Además la exposición a etanol tipo atracón durante la adolescencia disminuyó la actividad basal de c-fos en la adultez en el núcleo central de la amígdala y en el núcleo arqueado del hipotálamo. Concluimos que el consumo de alcohol en atracón durante la adolescencia causa problemas a largo plazo en la actividad basal de regiones cerebrales implicadas en el consumo de alcohol.

PALABRAS CLAVE: C-Fos; Inmunorreactividad; Ratas; Administración de alcohol en atracón; Adolescentes; Núcleo arqueado del hipotálamo (Arc); Núcleo central de la amígdala (CeA); Núcleo paraventricular del hipotálamo (PVN).

\section{REFERENCES}

Allen, C. D.; Lee, S.; Koob, G. F. \& Rivier, C. Immediate and prolonged effects of alcohol exposure on the activity of the hypothalamic-pituitary-adrenal axis in adult and adolescent rats. Brain Behav. Immun., 25(Suppl. 1):S50-60, 2011.

Brasser, S. M. \& Spear, N. E. Physiological and behavioral effects of acute ethanol hangover in juvenile, adolescent, and adult rats. Behav. Neurosci., 116(2):305-20, 2002.

Chang, S. L.; Patel, N. A. \& Romero, A. A. Activation and desensitization of Fos immunoreactivity in the rat brain following ethanol administration. Brain Res., 679(1):89-98, 1995.

Cone, R. D. Anatomy and regulation of the central melanocortin system. Nat. Neurosci., 8(5):571-8, 2005.

Cubero, I.; Navarro, M., Carvajal, F., Lerma-Cabrera, J.M. \& Thiele, E. Ethanol-induced increase of agouti-related protein (AgRP) immunoreactivity in the arcuate nucleus of the hypothalamus of C57BL/6J, but not 129/SvJ, inbred mice. Alcohol. Clin. Exp. Res., 34(4):693-701, 2010.

Curran, T. \& Morgan, J. I. Fos: an immediate-early transcription factor in neurons. J. Neurobiol., 26(3):403-12, 1995.

Gilpin, N. W. \& Roberto, M. Neuropeptide modulation of central amygdala neuroplasticity is a key mediator of alcohol dependence. Neurosci. Biobehav. Rev., 36(2):873-88, 2012.

Lerma-Cabrera, J. M.; Carvajal, F.; Alcaraz-Iborra, M.; de la Fuente, L.; Navarro, M.; Thiele, T. E. \& Cubero, I. Adolescent bingelike ethanol exposure reduces basal a-MSH expression in the hypothalamus and the amygdala of adult rats. Pharmacol. Biochem. Behav.,110:66-77, 2013.
Lerma-Cabrera, J. M.; Carvajal, F.; de la Torre, L.; de la Fuente, L.; Navarro, M.; Thiele, T. E. \& Cubero, I. Control of food intake by MC4-R signaling in the lateral hypothalamus, nucleus accumbens shell and ventral tegmental area: interactions with ethanol. Behav. Brain Res., 234(1):51-60, 2012.

Logrip, M. L.; Rivier, C.; Lau, C.; Im, S.; Vaughan, J. \& Lee, S. Adolescent alcohol exposure alters the rat adult hypothalamicpituitary-adrenal axis responsiveness in a sex-specific manner. Neuroscience, 235:174-86, 2013.

Navarro, M.; Cubero, I.; Chen, A. S.; Chen, H. Y.; Knapp, D. J.; Breese, G. R.; Marsh, D. J. \& Thiele T. E. Effects of melanocortin receptor activation and blockade on ethanol intake: a possible role for the melanocortin-4 receptor. Alcohol. Clin. Exp. Res., 29(6):949-57, 2005.

Navarro, M.; Lerma-Cabrera, J. M.; Carvajal, F.; Lowery, E. G.; Cubero, I. \& Thiele, T. E. Assessment of voluntary ethanol consumption and the effects of a melanocortin (MC) receptor agonist on ethanol intake in mutant C57BL/6J mice lacking the MC-4 receptor. Alcohol. Clin. Exp. Res., 35(6):1058-66, 2011.

Nestler, E. J. Historical review: Molecular and cellular mechanisms of opiate and cocaine addiction. Trends Pharmacol. Sci., 25(4):210-8, 2004.

National Institute on Alcohol Abuse and Alcoholism. NIAAA council approves definition of binge drinking. NIAAA Newsletter, 3:3, 2004.

Observatorio Chileno de Drogas. Servicio Nacional para la Prevención y Rehabilitación del Consumo de Drogas y Alcohol, (SENDA). Décimo estudio nacional de drogas en población 
LERMA-CABRERA, J. M.; CARVAJAL, F.; ALCARAZ-IBORRA, M.; SANCHEZ-AMATE, M. C.; DE LA FUENTE, L. \& CUBERO, I. Repeated binge-like ethanol administration during adolescence cause decreased c-fos immunoreactivity in amygdala and arcuate nucleus in adult Sprague-Dawley rats. Int. J. Morphol., 32(2):575-582, 2014.

general de Chile. Santiago de Chile, Ministerio del Interior y Seguridad Pública, 2013. Available in: http:// www.senda.gob.cl/wp-content/uploads/2011/04/ 2012_Decimo_EstudioNacional.pdf

Ogilvie, K. M.; Lee, S. \& Rivier C. Divergence in the expression of molecular markers of neuronal activation in the parvocellular paraventricular nucleus of the hypothalamus evoked by alcohol administration via different routes. J. Neurosci., 18(11):4344-52, 1998.

Pascual, M.; Boix, J.; Felipo, V. \& Guerri, C. Repeated alcohol administration during adolescence causes changes in the mesolimbic dopaminergic and glutamatergic systems and promotes alcohol intake in the adult rat. J. Neurochem., 108(4):920-31, 2009.

Paxinos, G. \& Watson, C. The rat brain: in stereotaxic coordinates. $4^{\text {th }}$ ed. San Diego, Academic Press, 1998.

Przybycien-Szymanska, M. M.; Mott, N. N., Paul, C. R.; Gillespie, R. A. \& Pak, T. R. Binge-pattern alcohol exposure during puberty induces long-term changes in HPA axis reactivity. PLoS One, 6(4):e18350, 2011.

Ryabinin, A. E.; Criado, J. R.; Henriksen, S. J.; Bloom, F. E. \& Wilson, M. C. Differential sensitivity of c-Fos expression in hippocampus and other brain regions to moderate and low doses of alcohol. Mol. Psychiatry, 2(1):32-43, 1997.

Silveri, M. M. \& Spear, L. P. Ontogeny of ethanol elimination and ethanol-induced hypothermia. Alcohol, 20(1):45-53, 2000.

Substance Abuse and Mental Health Services Administration, Office of Applied Studies. The TEDS Report: Substance Abuse Treatment Admissions Involving Abuse of Pain Relievers: 1998 and 2008. Rockville, MD, 2010.

Thiele, T. E.; van Dijk, G. \& Bernstein, I. L. Ethanol-induced cFos expression in rat lines selected for low and high alcohol consumption. Brain Res., 756(1-2):278-82, 1997.

Thiele, T. E.; van Dijk, G.; Yagaloff, K. A.; Fisher, S. L.; Schwartz, M.; Burn, P. \& Seeley, R. J. Central infusion of melanocortin agonist MTII in rats: assessment of c-Fos expression and taste aversion. Am. J. Physiol., 274(1 Pt. 2):R248-54, 1998.

Vilpoux, C.; Warnault, V.; Pierrefiche, O.; Daoust, M. \& Naassila, M. Ethanol-sensitive brain regions in rat and mouse: a cartographic review, using immediate early gene expression. Alcohol. Clin. Exp. Res., 33(6):945-69, 2009.

\section{Correspondence to:}

Dr. José Manuel Lerma Cabrera

Carrera de Psicología

Universidad Autónoma de Chile

Santiago de Chile

CHILE

Email: jose.lerma@uautonoma.cl

Received: 10-12-2013

Accepted: 28-03-2014 